\title{
8: 28407692-28477901
}

National Cancer Institute

\section{Source}

National Cancer Institute. 8: 28407692-28477901. NCI Thesaurus. Code C42347.

Physical location of FZD3_Gene 